\title{
Subject teachers' perceptions of academic mentoring and counseling services
}

\author{
Sutirna Sutirna*) \\ Universitas Singaperbangsa Karawang, Indonesia \\ ${ }^{*}$ Corresponding author, $\equiv$ e-mail: sutirna@staff.unsika.ac.id
}

\begin{abstract}
In developing students' potential requires, among others, psycho-education services. This effort can be provided not only by counselor but also by subject teachers at school. This research is aimed at investigating subject teachers' perceptions of academic guidance and counseling services provided by the teachers to students who had learning difficulties. Employing descriptive method, this research involved fifty counseling and guidance teachers to participate as research participants. To collect data, paper- and online-based questionnaires were used. The data gathered were then categorized and analyzed. The results indicated that the majority of the subject teachers have sufficient understanding on their roles in substantially providing academic guidance and counseling related to the students' academic problems. In addition, it was found that the counseling teachers always give the students referral to their respective teachers whenever the students get learning difficulties.
\end{abstract}

Keywords: perception, guidance and counseling, learning difficulties

How to Cite: Sutirna, S. (2019). Subject teachers' perceptions of academic mentoring and counseling services. COUNS-EDU: The International Journal of Counseling and Education, 4(4), 129-133. DOI: http://doi.org/10.23916/0020190423040

This is an open access article distributed under the Creative Commons Attribution License, which permits unrestricted use distribution, and reproduction in any medium, provided the original work is properly cited. (C2019 by author.

\section{Introduction}

It has been a consensus that developing life competency requires an integrated educational service system in each educational unit. This effort does not only rely on subject learning services/fields of study and management, but also on special psycho-educational services through guidance and counseling services (See Permendikbud No. 111 of 2014). In addition, efforts to develop the students' potential fully and optimally is a collaborative task involving teachers, counselors, and other educators as partners (Guidance and Counseling Implementation in Formal Education).

Based on the Ministry of Education and Culture and the Regulations of Guidance and Counseling, the efforts of developing students is a shared responsibility of stakeholders (teachers, principals, counselors, and educational staffs). Viewed from functional partnership between counselor and teachers, the problems of student development faced by the teacher related to learning processes will be referred to the counselor. The counselor otherwise will also refer students who have learning difficulties in particular subjects to the respective subject teacher.

Learning difficulties experienced by students actually stem from teaching and learning activities in the classroom. This means that in developing a quality learning process the teacher needs to pay attention to the implementation of the guidance and counseling functions. Thus, it is expected that learning difficulties experienced by students could be overcome. This is consistent with the relevancies and 
specificity of learning services provided by teachers, and guidance and counseling services by counselors. Pilon (2010) said In all realms of contemporary science, to understand, describe and act upon reality, an allencompassing sense of totality is needed, which demands complex thought, transdisciplinary approaches and conceptual maps based on new paradigms and rules of legitimacy and coherence.

Table 1. The uniqueness and interrelation of teacher and counselor services

\begin{tabular}{cll}
\hline Dimension & \multicolumn{1}{c}{ Teacher } & \multicolumn{1}{c}{ Counselor } \\
\hline Activity Focus & $\begin{array}{l}\text { Ability development of subject matters } \\
\text { and its problems }\end{array}$ & $\begin{array}{l}\text { Development of personal potential in the } \\
\text { personal, social, learning, and career fields } \\
\text { and their problems }\end{array}$ \\
\hline
\end{tabular}

However, in reality subject teachers in schools often find students experiencing academic problems other than personal, social, career, etc., which are not possible to be handled by the guidance and counseling teacher alone. It is clear that counseling guidance services must be carried out by the respective subject teacher. In this case, the guidance and counseling teacher must conduct a referral to the subject teacher so that the handling of the problem would be optimal. It is this optimal guidance and counseling service activity that will help students achieve their academic potential. Ganies Putra (2018) said sustainable Development Professionalism is a guide to continuous learning for teachers as the main line to bring about the changes that related to student success.

Furthermore Kartadinata (2008) said that quality, effective and ideal education is education that integrates three main areas of activity in synergy, namely the administrative and leadership fields, instructional or curricular fields, and guidance and counseling field. It may imply that education that only carries out administrative and instructional fields but put aside guidance and counseling will only produce counselees who are academically smart and skilled, but personally lack the ability or maturity. This was said by Kurniawan (2018) that "The era of globalization exposes the whole country to complex and rapid developments and changes. Every component of society within a country, required to race, improve its competence. The global situation makes life more competitive and opens opportunities for anyone to achieve better status and life. The positive impact of global conditions is to encourage individuals to continue to think and improve their ability, and not satisfied with something that is achieved at this time".

\section{Method}

This study is aimed at investigating subject teachers' perceptions of academic guidance and counseling services for students who experience learning difficulty. The method used in this research is descriptive research method. The population and sample of this study involved all subject teachers in Karawang Regency. Data were collected using an online questionnaire that was distributed to research respondents via the WhattsApp message. Respondents were then asked to fill out the questionnaire by clicking on the URL link (Uniform Resource Locator) that was sent by the author. The respondents were asked to respond to questions and statements by choosing one of four Likert scale choices, namely Strongly Agree (SS), Agree (S), Disagree (TS) and Strongly Disagree (STS).

Table 2. Percentage criteria for questionnaire perception

\begin{tabular}{clll}
\hline No & \multicolumn{1}{c}{ Percentage } & Category \\
\hline $\mathbf{1}$ & $\mathrm{P}=100 \%$ & All & \\
$\mathbf{2}$ & $76,00 \% \leq \mathrm{P}<100 \%$ & Almost All & \\
$\mathbf{3}$ & $50,00 \%<\mathrm{P}<76,00$ & Majority & \\
$\mathbf{4}$ & $\mathrm{P}=50,00 \%$ & Half & \\
$\mathbf{5}$ & $26,00 \% \leq \mathrm{P}<50,00 \%$ & Almost Half & \\
$\mathbf{6}$ & $0,00 \%<\mathrm{P}<26,00 \%$ & Minority & \\
$\mathbf{7}$ & $\mathrm{P}=0 \%$ & None & \\
\hline
\end{tabular}

Adapted from Fazri (2012) 
The respondents responses were calculated using simple statistical calculations to find the percentage of respondents' answers by the formula: $\mathrm{P}=\mathrm{f} / \mathrm{n} \times 100 \%$, with $\mathrm{P}=$ Percentage Value, $\mathrm{f}=$ Frequency of Answers, and $\mathrm{n}=$ number of respondents.

\section{Results and Discussions}

The subject teachers should provide Guidance and Counseling services to students who have learning difficulties as part of their duties.

The results showed almost half of the total respondents expressed Strongly Agree (40.86\%) and Agree $(38.05 \%)$ that the guidance and counseling teacher must make a referral of students who have difficulty learning to teachers of their respective subjects (For example Mathematics, English, Science, etc.). This referral is possible because subject teachers are considered knowledgeable aobut the subject matter than counseling teachers. This is in line with the Ministry of Education and Culture Regulation No. 111 of 2014 and Guidelines for the Implementation of Guidance and Counseling in Secondary Schools. According to Beatrice Asante Somuah, at.al (Matemilola : 1991), knowing the counseling needs of students can always provide a valid basis for providing the essential guidance service through which students can learn new coping mechanisms or seek help for those problems they cannot handle.

The respondents who stated Disagree and Strongly Disagree were 9.95\% and $11.14 \%$ respectively. This means that only a small percentage of teachers disagree if guidance and counseling services in the area of learning difficulties are resort to the teachers of their respective subjects.

Table 3. Subject teachers must provide Guidance and Counseling services to students who have learning difficulty.

\begin{tabular}{llcccc}
\hline No & Statement & \multicolumn{3}{c}{ OPTIONS } \\
\cline { 3 - 5 } & & SA (\%) & A (\%) & D (\%) & SD (\%) \\
1 & $\begin{array}{l}\text { Subject teachers must provide guidance and counseling services } \\
\text { for students who have learning difficulty. }\end{array}$ & 40.86 & 38.05 & 9.95 & 11.14 \\
\hline
\end{tabular}

Source: questionnaire number 1

Based on the Table 3 it is showed that the subject teachers in general has understood the implementation of guidance and counseling services in schools for the academic field to overcome the learning difficulties of the subjects. This is an effort to implement a synergistic guidance and counseling service among stakeholders in schools, and thus provide reinforcement through the socialization of Permendikbud No. 111 of 2014 concerning guidance and counseling in primary and secondary education from related parties such as supervisors and education affair.

Ebizie Elizabeth Nkechi (2016) to say "The implication for guidance and counselling is that the teacher observes the students during and after the class. The teacher also evaluate the students to know their knowledge of assimilation and if there is need for counselling, the teacher may which to invite the counsellor to the class for general class discussion of refer a particular students that is deficient to the counsellor for guidance section".

\section{Because I am a subject teacher, I do not need to have knowledge about Guidance and Counseling services.}

From the results it was revealed that the majority of respondents stated Strongly Disagree (62.95\%), and a small portion stated Disagreement (25.71\%) in terms of the necessity of subject teachers to have knowledge about Guidance and Counseling services. Thus it can be concluded that respondents strongly disagree with the statement that subject teachers do not need to understand guidance and counseling services. This finding is in accordance with one of the teacher roles, namely the teacher as an educator, instructor and supervisor in carrying out their main tasks and functions in school. 
Table 4. Because I am a subject teacher, I do not need to have knowledge about Guidance and Counseling services

\begin{tabular}{llcccc}
\hline No & Statement & \multicolumn{3}{c}{ OPTIONS } \\
\cline { 3 - 7 } & & SA (\%) & A (\%) & D (\%) & SD (\%) \\
2 & $\begin{array}{l}\text { Because I am a subject teacher, I do not need to have } \\
\text { knowledge about Guidance and Counseling services. }\end{array}$ & $\mathbf{5 . 5 7}$ & $\mathbf{5 . 7 6}$ & $\mathbf{2 5 . 7 1}$ & $\mathbf{6 2 . 9 5}$
\end{tabular}

Source: questionnaire number 2

Table 4 indicates that a small proportion of respondents stated strongly agree (5.57\%) and agree $(5.76 \%)$. Thus, the socialization of guidance and counseling services for subject teachers is very important to avoid misconceptions regarding the role of subject teachers as counselors for students who have learning difficulties. This reinforced opinion Muijs D. And Reynolds D. (Müyesser Ceylan and Esra Turhan, 2010) that teacher is the director of teaching process, he/she is an orchestrator.He/she is the one who spreads the content like a supervisor or an advisor (guidance) and also the one who performs teaching. Teacher is the one who teaches learning to the students. Therefore, perception because I am a subject teacher, I do not need to have knowledge about Guidance and Counseling services is wrong perception.

Duties and roles of subject teachers do not include Guidance and Counseling Services.

Data shows that almost half of the total respondents stated Disagree (47.43\%) and Strongly Disagree $(34.29 \%)$ if the duties and roles of the subject teachers do not include Guidance and Counseling Services. In addition, a small portion of respondents stated Strongly Agree (6.57\%) and Agree (16.71\%) to the statement. From this term, it is important to emphasize the role and function of subject teachers as counselors. This is because there are parts of the guidance that cannot be done by guidance and counseling teachers, including problems specific to subject matters. Ebizie Elizabeth Nkechi (2016) to say "The teacher in a classroom condition act as a counsellor in the form of Teaching Advisory Programme (TAP); in the light of this situation the teacher counsel the students in the right direction to take using life instance and experience to act of a guide since the students already see him/her as a role model".

Table 5: Duties and roles of subject teachers do not include guidance and counseling services.

\begin{tabular}{|c|c|c|c|c|c|}
\hline \multirow[t]{2}{*}{ No } & \multirow[t]{2}{*}{ Statement } & \multicolumn{4}{|c|}{ OPTIONS } \\
\hline & & SA (\%) & A (\%) & D (\%) & SD (\%) \\
\hline 3 & $\begin{array}{l}\text { Duties and roles of subject teachers do not include Guidance } \\
\text { and Counseling Services. }\end{array}$ & 6.57 & 16.71 & 42.43 & 34.29 \\
\hline
\end{tabular}

Source: questionnaire number 3

\section{Subject teachers must grasp the competency of Guidance and Counseling service skills for students who experience academic problems.}

The data shows that almost half of the total respondents stated strongly agree (47.43\%) and agree (33.48\%) that subject teachers are required to master competency in Guidance and Counseling service skills for students who experience academic problems. A small percentage of respondents have a wrong perception about the guidance and counseling service skills.

\section{Conclusions}

Based on the presentation of the findings and discussion above, it can be concluded several points as follows: 1) The majority of subject teachers understand their role as mentors in guidance and counseling services for the academic field, especially the problem of learning subject matter substantially; 2) Teacher guidance and counseling should conduct referral activities to subject teachers if there are students who have difficulty in learning subject matter. This is in accordance with the guidelines for implementing guidance and counseling. 


\section{References}

Beasiswa, F. P. (2012, April -). Profil Kemampuan Dasar Guru. P. 1.

Beatrice Asante Somuah, at.al. (2014). An Investigation into the Study Habits of Distance Learners: Implications for Guidance and Counseling Services. Mediterranean Journal of Social Sciences MCSER Publishing, Rome-Italy. Vol. 5 No. 6

Depdiknas. (2008). Penataan Pendidikan Profesional Konselor Dan Layanan Bimbingan Dan Konseling Dalam Jalur Pendidikan Formal. Jakarta: Depdiknas.

Djauhari, M. (2017, Mei -). Researchgate. Retrieved April 03, 2019, From Https://Www.Researchgate.Net/Publication/316735866_Pengembangan_Profesionalisme_Guru_ Menuju_Indonesia_Gemilang: Https://Www.Researchgate.Net

Ebizie Elizabeth Nkechi, at.al (2016). The Role of Guidance and Counselling in Effective Teaching and Learning in Schools. RAY: International Journal of Multidisciplinary Studies, E-ISSN: 2456-3064, Volume I, No. 2, October, 2016, pp. 36-48.

Fakhurohman, J. (2019, - -). Www.Academia.Edu. Retrieved April 03, 2019, From Www.Academia.Edu: Http://Www.Academia.Com

Ganies Putra (2018). Development Model of Professionalism Guidance and Counseling Teacher. 4th International Conference on Early Childhood Education. Semarang Early Childhood Research and Education Talks (SECRET 2018). Atlantis Press- Advances in Social Science, Education and Humanities Research, volume 249.

Kartadinata, S. (2008). Kompilasi Konseling Lintas Budaya. In S. Kartadinata, Konseling Lintas Budaya (P. 125). Bandung: Pascasarjana Upi.

Kebudayaan, D. P. (2005). Undang Undang No. 14 Tahun 2005 Tentang Guru Dan Dosen. Jakarta: Departemen Pendidikan Dan Kebudayaan.

Kurniawan Fandy (2018). Development of annual program guidance and counseling in higher education. COUNS-EDU The International Journal of Counseling and Education Vol.3, No.3, September 2018, pp. 108114.

Kusmiharto, H. (2007, September 09). Http://File.Upi.Edu/Direktori/Fip/Jur._Pend._Luar_Sekolah. Retrieved Januari 23, 2019, From Http://File.Upi.Edu/Direktori/Fip/Jur._Pend._Luar_Sekolah: Http://Www.Upi.Edu

Matemilola, S. (1991). Counselling needs of adult N. C. E. part-time students of the College. Osiele, Abeokuta. Unpublished M. Ed. Project, University of Ilorin. Nigeria.

Mohammad, M. (2107, Oktober 19). Kompasiana.Com. Retrieved April 03, 2019, From Www.Kompasiana.Com: Http://Www.Kompasiana.Com

Müyesser Ceylana and Esra Turhan (2010). Student-teachers' opinions about education and teaching profession example of Anadolu University. Procedia Social and Behavioral Sciences 2 (2010) 22872299.

Nasional, D. P. (2008). Penataan Pendidikan Profesional Konselor Dan Layanan Bimbingan Dan Konseling Dalam Jalur Pendidikan Formal. Bandung: Jurusan Psikologis Pendidikan Dan Bimbingan, Fip Upi Bandung.

Natawidjaja, R. (1984). Pendidikan (Studi Dan Pengajaran). Jakarta: Depdikbud.

Pilon F. André, (2010). Living better in a better world: Guidance and counselling in the ecosystemic model of culture. Procedia Social and Behavioral, 1-17.

Riyanto, T. (2002). Pembelajaran Sebagai Suatu Bimbingan Pribadi. Jakarta: Grasindo.

Sunaryo. (2008). Pendidikan Yang Bermutu. Bandung: Upi.

Surya, M. (2004). Psikologi Pembelajaran Dan Pengajaran. Bandung: Pustaka Bani Quraisy.

Suryono, B. (2016). Public Trust Dan Profesi Bk Bermartabat Menuju Karakter Konselor Yang Dibutuhkan. E_Journal Unipma, 1-24.

Sutirna. (2004). Model Pembelajaran Matematika Bernuansa Bimbingan Di Sltp. Bandung: Pascasarjana Upi.

Sutirna. (2017). Persepsi Guru PAI SMP/MTs Se Kabupaten Karawang Terhadap Layanan Bimbingan Dan Konseling. Wahana Karya Ilmiah Pendidikan, 1-13.

Sutirna. (2019). Bimbingan Dan Konseling Bagi Guru Mata Pelajaran. Karawang: -. 